\title{
INICJATYWY PRACOWNIKÓW SOCJALNYCH PODEJMOWANE WOBEC OSÓB STARSZYCH W ŚRODOWISKU ZAMIESZKANIA. NA PRZYKŁADZIE WYBRANYCH PROJEKTÓW SOCJALNYCH
}

\begin{abstract}
Social worker initiatives taken against the elderly in the living environment. On the example of selected social projects
\end{abstract}

The content of the article focuses on the issues of the elderly and the role of a social worker in the local environment. The aim of the article is to show the initiatives taken by social workers taking into account the problems and needs of older people. The source material has become social projects implemented by social workers who raise their qualifications and apply for second degree specialization. The research method is the analysis of existing data, in this case social projects. Social projects were implemented in 2017-2018. The article presents only selected projects, and thus also the problems of seniors. Social workers through projects prove how much can be done for older people thanks to the ingenuity, willingness and integration of social service forces in a given local community. At the same time, they show what problems elderly people are facing and what challenges they face in society.

Key words: elderly person, social worker, social work method, social project

\section{Wprowadzenie}

Żyjemy w czasach naznaczonych starzejącym się społeczeństwem. Wiele programów polityki społecznej uwzględnia wsparcie osób starszych. Najbardziej jednak znamiennym przykładem jest polityka senioralna. Jak słusznie zauważa Jerzy Krzyszkowski, demografię Polski kształtują dwa zjawiska: niska dzietność i coraz większa długość życia (2018: 38). Fakt, że żyjemy dłużej, jest zjawiskiem pozytywnym. Ludzie pracujący partycypują w systemie ubezpieczeń społecznych, zabezpieczając się przed ryzykami życiowymi. Wśród ryzyk wymienia się starość - jako jedyne ryzyko pozytywne, to jest takie, że każdy pragnie, aby go dosięgło. Życzenia 100 lat w zdrowiu i z wysokimi świadczeniami emerytalnymi są odbierane z najwyższą aprobatą. Sam wydłużony wiek 
życia człowieka XXI wieku jest zatem zjawiskiem pożądanym i oczekiwanym przez stulecia. Natomiast problemy związane ze starzejącym się społeczeństwem stają się pochodną innych czynników, jak na przykład niż demograficzny, brak zastępowalności pokoleń czy malejąca liczba ludzi pracujących w przeliczeniu na jednego emeryta. Do tego doliczyć należy przemiany strukturalne i składu rodzin, to jest wzrost liczby rodzin nuklearnych, a spadek rodzin wielopokoleniowych. W rodzinach tradycyjnych, wielopokoleniowych nie było problemu opieki nad seniorami. Mechanizmy opiekuńcze działały w dwie strony. Najpierw rodzice sprawowali opiekę nad dziećmi, a następnie wnukami, po czym dorosłe dzieci (niejako spłacając dług wdzięczności) pełniły funkcje opiekuńcze wobec rodziców. Ogólnie dzieci stanowily zabezpieczenie dla rodziców. Współcześnie te mechanizmy opiekuńczo-zabezpieczające przestały działać, rodziny wielopokoleniowe wyraźnie się skurczyły, a to przekłada się na samotność seniorów i problem braku opieki nad nimi.

Naprzeciw tym wyzwaniom związanym z samotnością, rosnącą liczbą populacji seniorów i deficytami opieki wychodzą różne instytucje, między innymi ośrodki pomocy społecznej i zatrudnieni w nich pracownicy socjalni. Najbardziej rozpowszechnioną formą pomocy jest praca socjalna. W amerykańskiej tradycji pracę socjalną traktuje się jako działalność usługową, zaliczaną do tak zwanej sfery socjalnej i rozumie się ją na dwa sposoby. Z jednej strony jako zawód, profesję, z drugiej jako personal social services, to jest osobiste usługi społeczne obejmujące dbałość o rozwój jednostek i ich uspołecznienie, opiekę nad osobami z różnego rodzaju zaburzeniami i deficytami w postaci terapii, rehabilitacji oraz ochrony, a także udzielenie informacji i poradnictwo, w tym zapewnienie dostępu do specjalistycznych usług (Szatur-Jaworska 1995: 107-108).

Celem pracy socjalnej na rzecz seniorów jest dążenie do poprawy jakości ich życia, do godnego starzenia się poprzez aktywizację społeczną. Według Międzynarodowej Federacji Pracowników Socjalnych (International Federation Social Workers) praca socjalna to zawód wspierający:

zmianę społeczną, rozwiązywanie problemów powstających w relacjach międzyludzkich oraz wzmacnianie i wyzwalanie ludzi dla wzbogacania ich dobrostanu. Wykorzystując teorie ludzkich zachowań i systemów społecznych, praca socjalna interweniuje w miejscach, gdzie ludzie wchodzą $\mathrm{w}$ interakcje ze środowiskiem. Fundamentalnymi dla pracy socjalnej są zasady praw człowieka i sprawiedliwości społecznej (cyt. za: Kijak, Szarota 2013: 41).

Ogólną ideą, sensem i celem pracy socjalnej jest, zgodnie z myślą Heleny Radlińskiej i jej kontynuatorów:

mobilizowanie osób (...), lokalnych środowisk do samodzielnych działań, ujawnienie i umiejętne (profesjonalne) wykorzystanie sił i możliwości tkwiących w tych osobach, rodzinach i grupach, wskazywanie najlepszych sposobów osiągnięcia celu, jakim jest przezwyciężenie trudnych sytuacji życiowych i odzyskanie zdolności do samodzielnego funkcjonowania w społeczeństwie (Szarota 2010: 165). 
Pracownicy socjalni podejmują działania wyznaczone aktami prawnymi, w tym ustawą o pomocy społecznej. Zgodnie $z$ art. 6 pkt 12 Ustawy o pomocy społecznej z dnia 12 marca 2004 roku pracę socjalną określa się jako:

działalność zawodową mającą na celu pomoc osobom i rodzinom we wzmacnianiu lub odzyskiwaniu zdolności do funkcjonowania w społeczeństwie poprzez pełnienie odpowiednich ról społecznych oraz tworzenie warunków sprzyjających temu celowi (Dz.U. z 2004 r. Nr 64 poz. 593).

Najbardziej znane i szerokie określenie pracy socjalnej odnajdujemy w programie nauczania pracowników socjalnych jako:

działanie mające na celu usprawnienie społecznego funkcjonowania jednostek, tak indywidualne, jak i w grupie, poprzez działania skierowane na ich stosunki społeczne, rzutujące na interakcje między człowiekiem a jego otoczeniem. Działania te dzielą się na trzy grupy funkcjonalne: odnowienie utraconej lub osłabionej zdolności, zapewnienie zasobów indywidualnych i zbiorowych oraz zapobieganie społecznej dysfunkcji (Skidmore, Thackeray 1996: 18).

Misja pracy socjalnej została powierzona pracownikom socjalnym, którzy realizują zadania, wykorzystując:

własne zasoby społeczne i osobiste, profesjonalnie pomagają ludziom radzić sobie z problemami, usprawniają zarówno ich indywidualne zdolności, jak i umożliwiają sprawniejsze funkcjonowanie systemu wsparcia społecznego poprzez inicjowanie kontaktów między służbami, wpływanie na ich funkcjonowanie, a także realizację polityki społecznej (Ornacka 2012: 47).

Praca z osobami starszymi wymaga specjalnych umiejętności zawodowych od pracownika socjalnego, między innymi delikatności, umiejętności rozmowy i słuchania, empatii itp. Dlatego Zofia Szarota proponuje - biorąc pod uwagę także wyzwania związane ze starzejącym się społeczeństwem - kształcenie gerontologiczne pracowników socjalnych:

Nieodległa przyszłość musi przynieść nowy zawód, zgodny z nową jakością potrzeb społecznych: gerontopedagoga. Nazwa sugeruje usytuowanie specjalności w programach kształcenia pedagogicznego. Zadaniem absolwenta będzie aktywizacja pokolenia trzeciego i czwartego wieku, organizacja czasu wolnego, doradztwo geragogiczne, poszukiwanie i kształcenie wolontariuszy. Studia przygotowujące do tego zawodu powinny opierać się na wiedzy i umiejętnościach pedagogicznych multidyscyplinarnie połączonych z demografią, ekonomią, socjologią i psychologią (...). Studia powinny umożliwić gerontopedagogom zdobycie kompetencji w zakresie doradztwa geragogicznego, animacji społeczno-kulturalnej i metod pracy socjalnej i kulturalno-oświatowej (...). Czynności gerontopedagoga/geragoga powinny polegać na wypełnianiu roli diagnosty potrzeb osób starszych, ich doradcy, pośrednika i organizatora aktywności i życia codziennego. Zatrudnienie winien znajdować głównie w placówkach pomocy społecznej, ale i w poradniach geragogicznych, ośrodkach spotkań i klubach seniora, w sanatoriach i domach wypoczynkowych 
dla osób starszych, w stowarzyszeniach senioralnych i grupach wzajemnej pomocy przedstawicieli tego pokolenia (Szarota 2010: 280-281).

Kształcenie specjalistów, w tym i pracowników socjalnych do pracy z osobami starszymi, jest nie tylko „życzeniem”, ale w najbliższej przyszłości powinno stać się wyzwaniem i koniecznością, jeżeli w sposób profesjonalny pragniemy pomagać seniorom.

Aktualnie w pracy z osobami starszymi dominują różne nurty, metody, propozycje. Jak podkreślają badacze problematyki (Kijak, Szarota), najbardziej pożądana i stosowana jest metoda indywidualnych przypadków. Wynika ona $\mathrm{z}$ tego, iż praca z osobą starszą jest trudna i absorbująca. Pracownik socjalny ma jednak do wyboru wiele form pomocy seniorom i przyjmuje różne role, między innymi jest on koordynatorem działań innych specjalistów, przewodnikiem i doradcą dla osoby starszej, podejmuje działania wspierające, kierujące, podtrzymujące, informujące, towarzyszące, opiekuńcze, mediacyjne i motywujące (Kijak, Szarota 2013: 43-45). Stosowanie tej metody nie wyklucza innych metod pracy socjalnej, jak metoda pracy z grupą czy ze środowiskiem. Zawężenie działań tylko do jednej metody nie jest możliwe. Nie wszyscy seniorzy mieszkają samotnie - niektórzy z rodziną. Ponadto wielu z nich integruje się w ramach własnej społeczności lokalnej. Bagatelizowanie bliższego bądź dalszego otoczenia seniorów byłoby błędem. Dlatego wszystkie trzy metody pracy socjalnej w pomocy seniorom są niezbędne.

Na szczególną uwagę zasługuje trzecia metoda pracy socjalnej - środowiskowa. Najbardziej dosadnie tę metodę ujął Aleksander Kamiński, jako: „ulepszanie sytuacji zjednoczonymi siłami organizacji publicznych i społecznych, mobilizujących wszelkie siły społeczne, do działań w oparciu o wspólny plan, wypracowany przy pomocy odpowiednich badań kompleksowych" (1976: 124). Metoda ta polega na organizowaniu całych społeczności lokalnych poprzez wzmacnianie więzi społecznych oraz rozwijanie oddolnych inicjatyw samopomocowych. Jej celem jest zmiana funkcjonowania społeczności oraz poprawa poziomu i jakości życia tworzących ją ludzi. Integracja środowiska, budowanie więzi oraz wymiana i przepływ informacji stają się sprzymierzeńcami metody środowiskowej (Mielczarek 2010: 308-309).

Znacznie szerzej pomoc seniorom w środowisku zamieszkania ujmuje Barbara Szatur-Jaworska, proponując system wsparcia. Jako punkt wyjścia autorka przyjmuje pojęcie wsparcia w polityce społecznej, w myśl której: „relację wsparcia społecznego tworzą z jednej strony jednostki i małe grupy społeczne (głównie rodziny), zaś z drugiej instytucje oraz zorganizowane grupy funkcjonujące w sformalizowanych i niesformalizowanych strukturach" (Szatur-Jaworska 2017: 8). System wsparcia seniorów uwzględnia włączenie instytucji zarówno stacjonarnych, jak i tych o charakterze niestacjonarnym, jak na przykład placówki dziennego pobytu, czy nawet instytucji otwartych oferujących seniorom usługi w krótszym czasie i z mniejszą regularnością niż instytucje dziennego pobytu. W środowisku zamieszkania w systemie wsparcia seniora istotną rolę odgrywają instytucje o charakterze niestacjonarnym. Ich działalność jest ważna, gdyż umożliwia jak najdłuższe pozostanie seniora w środowisku zamieszkania (Szatur-Jaworska 2017: 8). 
W formach pomocy seniorom przewija się propozycja „polityki kreatywnego starzenia się”. Może być ona realizowana poprzez następujące zadania: zwiększenie uczestnictwa seniorów w kulturze, wspieranie zróżnicowania społecznego i kulturowego, stymulowanie inicjatyw artystycznych, poprawę dialogu międzypokoleniowego czy nawet zachęcanie do wolontariatu. Sami seniorzy mogą czerpać korzyści z kreatywnego starzenia się. Wymienić tu można chociażby: poczucie samorealizacji i dobrobytu, zwiększenie pewności siebie i poczucie własnej wartości, nowe doświadczenia edukacyjne, nowe korzyści społeczne i zaangażowanie, możliwość dzielenia się wiedzą i dziedzictwem kulturowym z młodszym pokoleniem, poprawę zdrowia psychicznego i fizycznego (Klimczuk 2013: 35). Biorąc pod uwagę zarówno rosnącą długość życia człowieka, jak i jego jakość (sprawność, edukację itp.), należy przypuszczać, iż polityka kreatywnego starzenia się będzie zyskiwała na znaczeniu.

\section{Projekty socjalne realizowane dla seniorów uczestników II stopnia specjalizacji w zawodzie pracownik socjalny}

Ustawodawca przewidział możliwość podnoszenia kwalifikacji przez pracowników socjalnych poprzez dwa stopnie specjalizacji zawodowej. Uściślając, I stopień specjalizacji zawodowej z zakresu pracy socjalnej ma na celu uzupełnienie wiedzy i doskonalenie umiejętności zawodowych pracowników socjalnych. Natomiast II stopień specjalizacji zawodowej to pogłębienie wiedzy i doskonalenie umiejętności pracy z wybranymi grupami osób korzystających z pomocy społecznej. W ramach specjalizacji II stopnia pracownicy socjalni mają możliwość wyboru jednej z dziesięciu proponowanych specjalności pracy socjalnej, to jest: (1) z rodziną i problemami opiekuńczo-wychowawczymi; (2) z osobą i rodziną z problemem przemocy; (3) z osobami niepełnosprawnymi i ich rodzinami; (4) z osobami z zaburzeniami psychicznymi i ich rodzinami; (5) z osobami starszymi; (6) z osobami bezrobotnymi; (7) z osobami uzależnionymi; (8) z osobami bezdomnymi; (9) z cudzoziemcami, mniejszościami narodowymi i etnicznymi; (10) pracę socjalną ze społecznością lokalną.

Z nadesłanych projektów socjalnych do Centralnej Komisji Egzaminacyjnej do spraw specjalizacji w zawodzie pracownik socjalny wynika, iż na przełomie lat 2017 i 2018 najczęściej wybieraną specjalnością była praca socjalna z osobami starszymi $(36,4 \%)$, następnie praca socjalna $\mathrm{z}$ osobą i rodziną z problemem przemocy $(32,6 \%)$, ze społecznością lokalną (10,9\%), z osobami uzależnionymi (10,9\%), z rodziną i problemami opiekuńczo-wychowawczymi (9,2\%). Jak wynika z wybieranych specjalności i realizowanych projektów, pracownicy socjalni mają świadomość, iż poważnym wyzwaniem staje się dla nich pomoc seniorom.

Projekty socjalne skierowane na pomoc seniorom można podzielić na trzy kategorie. Pierwszą stanowią projekty mające na celu aktywizację i integrację osób starszych. Obejmują one zarówno tych seniorów, którzy zamieszkują samotnie, jak i tych, których miejscem zamieszkania jest instytucja, czyli dom pomocy społecznej. Druga grupa 
projektów uwzględnia bezpieczeństwo seniorów. Praktyka pokazuje, iż seniorzy nie zawsze potrafią sami ochronić się przed różnego rodzaju nadużyciami, a nawet stają się ofiarami różnych manipulacji. Trzecia kategoria problemów obejmuje tych seniorów, którzy popadają w apatię, unikają kontaktów, izolują się, żyją niejako w „ukryciu”.

Warto nadmienić, iż wszystkie realizowane projekty są poprzedzone gruntowną diagnozą problemu i potrzeb beneficjentów, zawierają cele, metody realizacji, plan działania, mocne i słabe strony oraz szanse i zagrożenia, czyli tak zwaną analizę SWOT, harmonogram działań, budżet, przebieg realizacji, ewaluację, wnioski i postulaty. Niewątpliwym atutem każdego projektu jest pogłębiona diagnoza problemu, jego rozpoznanie, „drzewo problemów”, opis, wreszcie rozpoznanie potrzeb osób starszych. Dopiero tak przeprowadzona diagnoza problemu oraz weryfikacja rzeczywistych potrzeb seniorów i możliwości ich zaspokajania stanowią podstawę do realizacji projektu.

W niniejszym artykule zaprezentowano wybrane projekty pracowników socjalnych, skupione wokół wiodących problemów seniorów. Każdy z podrozdziałów będzie stanowił przynajmniej wycinek tytułu realizowanego projektu socjalnego.

\section{„Aktywny senior"}

Aktywizowanie i integracja osób starszych stanowią jeden z najczęściej wybieranych tematów w projektach socjalnych. Diagnoza problemów osób starszych przeprowadzona przez Alicję Ruszczyk w Gminie Gietrzwałd wykazała, iż charakteryzuje ich zazwyczaj niska aktywność społeczna i kulturalna. Przyczynami tego stanu są najczęściej: niska samoocena, niska motywacja do aktywnego spędzania czasu wolnego, niskie dochody, nieumiejętność poruszania się po ofertach kulturalnych, niska liczba ofert społecznych i kulturalnych dla seniorów w środowisku oraz niskie kompetencje społeczne i interpersonalne. Metodologią opracowania analizy SWOT autorka uczyniła technikę obserwacji oraz dane zastane. Do mocnych stron zaliczyła: dyspozycyjność osób starszych, bogatą ofertę kulturalną w gminie, zwiększającą się liczbę obiektów bez barier architektonicznych oraz wykształconą i kompetentną kadrę pomocy i integracji społecznej. Za słabe strony uznała: niski poziom wykształcenia seniorów, niską wiarę we własne możliwości, niskie poczucie własnej wartości, małe zdolności organizacyjne i analityczne, niski poziom aktywności społecznej, małą mobilność, niskie dochody, ograniczony dostęp do lekarzy specjalistów (szczególnie geriatrów), małą wiedzę na temat instytucji świadczących wsparcie, niewystarczającą liczbę punktów spotkań w miejscach zamieszkania $\mathrm{i}$ - co istotne - stereotypy w postrzeganiu seniorów typu: niedołężny, biedny, niezaradny, nienadążający za postępem technologicznym. Jako główny cel projektu przyjęto zwiększenie aktywności kulturalnej i społecznej seniorów korzystających z pomocy społecznej poprzez integrację z seniorami mieszkańcami własnej gminy. Celami szczegółowymi uczyniono: podniesienie kompetencji społecznych, podniesienie samooceny, podniesienie motywacji do aktywnego spędzania czasu wolnego, podniesienie umiejętności poruszania się po ofertach kulturalnych. Projekt zakładał pracę grupy opartej na 
spotkaniach, warsztatach i pogadankach w ciągu dwóch miesięcy. W projekt zaangażowano pracowników socjalnych, instruktora $\mathrm{z}$ gminnego ośrodka kultury oraz innych specjalistów, jak na przykład pielęgniarkę, dietetyka, policjanta. W ramach warsztatów seniorzy wykonywali różne prace plastyczne i maskotki, mieli możliwość wykazania swoich zdolności kulinarnych, odbył się także „wieczór seniora”. Zorganizowano również wyjazd do kina. Oceniając projekt, autorka zauważyła, iż nastąpiła widoczna przemiana seniorów, przejawiająca się otwartością mówienia o swoich problemach, pokonaniem lęku przed wyjściem z mieszkania, a także mobilizacją do aktywnego spędzania czasu wolnego. W realizacji projektu wzięło udział 9 seniorek. Ocena projektu przez seniorki pozwoliła na ustalenie następujących wniosków: wszystkie seniorki przyznały, iż zintegrowały się z innymi uczestnikami projektu; $8 \mathrm{z}$ nich wyraziło zadowolenie $\mathrm{z}$ uczestnictwa w projekcie i chciałoby uczestniczyć w kolejnych projektach; 7 seniorek rozszerzyło wiedzę w zakresie zagadnień poruszanych na szkoleniach, a 6 uczestniczek przyznało, iż główną przeszkodą w uczestnictwie w projektach jest pogarszający się stan zdrowia. Uczestniczki projektu przyznały, iż początkowo nie były chętne do udziału w projekcie, ale szybko przekonały się do niego i z niecierpliwością czekały na kolejne zajęcia. $\mathrm{W}$ podsumowaniu autorka niniejszego projektu napisała:

Projekt socjalny dotyczący osób starszych pozwolił zwrócić uwagę mieszkańców gminy na problem, a w szczególności na fakt, że wśród nas żyją osoby starsze, które wymagają wsparcia. Można stwierdzić jednoznacznie, że niska aktywność osób starszych i pozostawienie ich bez wsparcia stanowią realne zagrożenie dla naszych seniorów. Zatem konieczne jest dalsze podejmowanie działań dla osób starszych, aby w wieku emerytalnym łatwiej radzili sobie z problemami dnia codziennego (Ruszczyk 2017: 55).

Ciekawym projektem, mającym na celu zwiększenie aktywności seniorów, jest działanie na poziomie instytucji, takich jak Uniwersytety Trzeciego Wieku czy domy pomocy społecznej. Iwona Alejster postanowiła w ramach swojego projektu podnieść poziom aktywności osób starszych - uczestników UTW. Diagnozy problemów autorka dokonała za pomocą ankiety składającej się z 17 pytań, którą przeprowadziła wśród seniorów na UTW. Jako główny problem seniorów wykazano niski poziom aktywności po 60. roku życia. Kreśląc „drzewo problemów”, do przyczyn zaliczyła między innymi: problemy zdrowotne, bariery komunikacyjne, niski status materialny, brak ofert dla seniorów, niskie poczucie własnej wartości, oferty niedostosowane do statusu materialnego. Za skutki uznano: pogorszony stan zdrowia, wzrost wydatków na leczenie, ograniczenie kontaktów towarzyskich, poczucie osamotnienia i wykluczenia społecznego. Stosując analizę SWOT, do mocnych stron zaliczono: wiedzę, wykształcenie, doświadczenie zawodowe, mądrość życiową, dyspozycyjność, sprawność intelektualną i fizyczną. Za słabe strony uznano: niskie dochody, problemy zdrowotne, niski poziom motywacji do podjęcia aktywności, niskie poczucie własnej wartości, bariery komunikacyjne. Celami szczegółowymi projektu uczyniono: zwiększenie aktywności edukacyjnej i kulturalnej osób starszych, podtrzymywanie kontaktów towarzyskich, zwiększenie poziomu wiedzy w zakresie instytucjonalnej pomocy seniorom i przysługujących im świadczeń, 
poszerzenie wiedzy z zakresu zdrowego żywienia i zagrożeń wynikających ze stosowania nieodpowiednio zbilansowanej diety, podniesienie wiedzy o zagrożeniach wynikających ze zbyt długiego stosowania suplementów diety, witamin i minerałów oraz zdobycie wiedzy na temat skutków niesystematycznego przyjmowania leków. Realizacja projektu została oparta na metodzie pracy z grupą. Na wstępie zorganizowano tak zwany kiermasz integracyjny, mający na celu nawiązanie relacji i więzi grupowej. Następnymi etapami były: spotkania z pracownikiem socjalnym, farmaceutą, dietetykiem, a w ramach zwieńczenia projektu przygotowano ognisko integracyjne. Projekt został zrealizowany na przełomie dwóch miesięcy, to jest maja i czerwca. Wzięło w nim udział 10 seniorów. Oceniając projekt, autorka również przeprowadziła ankietę ewaluacyjną. Wszyscy uczestnicy ocenili projekt jako dobrze zorganizowany, zwiększający ich kontakty towarzyskie, niwelujący poczucie wykluczenia społecznego i osamotnienia, dodatkowo pogłębiający ich wiedzę w zakresie suplementów diety i zasad zdrowego żywienia. Seniorzy wyrazili chęć udziału w podobnych inicjatywach w przyszłości (Alejster 2017).

Seniorzy zamieszkujący w domu pomocy społecznej również mogą liczyć na inicjatywy integracyjne podejmowane przez pracowników socjalnych. Taki pomysł zrealizowały Irena Proć i Bożena Tomes w Domu Pomocy Społecznej we Wrocławiu. Jako główny problem zauważyły małą aktywność i niski stopień integracji mieszkańców DPS. Diagnoza problemów mieszkańców i ich potrzeb została opracowana na podstawie danych zastanych, takich jak: indywidualne karty oceny stanu zdrowia i wsparcia sporządzone przez pielęgniarkę, terapeutę, psychologa, instruktora terapii zajęciowej oraz pracownika socjalnego. Wśród przyczyn niskiej aktywności i integracji mieszkańców znalazły się: zły stan zdrowia, niepełnosprawność, brak oferty terapeutycznej dostosowanej do zainteresowań mieszkańców, brak środków na wprowadzenie nowych form terapeutycznych, stereotyp DPS jako instytucji totalnej oraz brak regularnych kontaktów mieszkańców ze środowiskiem lokalnym. Do skutków należą: osamotnienie, izolacja, brak autonomii, brak poczucia samorozwoju, niskie poczucie własnej wartości, brak możliwości realizacji własnych zainteresowań, niska aktywność dnia codziennego, brak poczucia wpływu na własne życie, brak partycypacji w życiu społecznym. Projekt miał na celu zwiększenie aktywności i integracji ze społecznością lokalną mieszkańców DPS. Celami szczegółowymi uczyniono dodatkowo zaspokojenie potrzeby samorealizacji mieszkańców oraz promowanie wizerunku DPS jako instytucji otwartej. Spośród mieszkańców wyłoniono grupę 10 osób zainteresowanych warsztatami teatralnymi, ze środowiska lokalnego zaś zaangażowano 7 seniorów. Łącznie zorganizowano 14 dwugodzinnych zajęć teatralnych. Warsztaty teatralne poprowadzili lokalni animatorzy kultury. Uwieńczeniem projektu był 50-minutowy multimedialny program słowno-artystyczny pod tytułem „Baw się razem z nami”, ukazujący barwne obrazy lat sześćdziesiątych XX wieku. Po zakończeniu projektu grupa złożona z 7 mieszkańców DPS i 6 seniorów ze środowiska lokalnego nadal organizuje cykliczne spotkania. Według autorki projektu: „Seniorzy z osiedla mieli okazję poznania świata DPS od wewnątrz, a nasi mieszkańcy z kolei mogli dowiedzieć się czegoś o życiu osiedla (s. 61). Warsztaty teatralne dla seniorów ocenione zostały jako doskonała forma aktywizacji i integracji 
społecznej, dająca możliwość kreatywnego wyrażenia siebie i budowania pozytywnych relacji międzyludzkich" (Proć, Tomes 2018).

Projekty socjalne realizowane z myślą o zwiększeniu aktywności seniorów mają ogromną wartość. Nade wszystko pozwalają na przezwyciężenie przekonania o niskiej samoocenie i niskiej wartości oraz stereotypu seniora jako człowieka „niepotrzebnego”, "nieużytecznego", „wycofanego", słowem: zepchniętego na margines społecznego życia. Zaprezentowane tylko wybrane projekty pokazują, jak wiele może uczynić pracownik socjalny dla seniorów oraz że proces aktywizacji i integracji seniorów dokonuje się małymi krokami, to jest w małych grupach i za pomocą dostępnych metod. Metody realizacji projektów pozwalają seniorom na przełamanie bariery samotności i bierności, a stają się szansą przynajmniej częściowego „kreatywnego starzenia się”. Nie ulega wątpliwości, iż seniorzy potrzebują wsparcia ze strony innych osób i instytucji. Tym, co może nas niepokoić, jest fakt, iż nawet seniorzy mieszkający w instytucjach takich jak DPS nie są w pełni aktywni. Dlaczego tak się dzieje? Czy dyrektorzy tych instytucji są świadomi potrzeb swoich mieszkańców i czy zatrudniony personel zasługuje na miano "fachowo pomagających"? Projekty pokazują, jak wiele zależy od samych pracowników socjalnych, ich chęci zaangażowania się, inicjatywy, pomysłu, przekonania do realizacji innych lokalnych podmiotów, a nade wszystko przełamania bariery nieśmiałości, bierności i stereotypu pracownika socjalnego ograniczonego li tylko do przyznawania zasiłku.

\section{„Bezpieczny senior”}

Bezpieczeństwo seniorów to drugi popularny temat w projektach socjalnych. Diagnoza pokazuje, iż seniorom nie tylko dokuczają: samotność, bierność, izolacja, ale są oni także potencjalnymi „ofiarami” różnego rodzaju nadużyć, manipulacji, a nawet przemocy. We współczesnym świecie na seniorów czyha wiele zagrożeń, dlatego potrzebne jest im wsparcie zarówno edukacyjne - zwiększające wiedzę o zagrożeniach - jak i to ze strony instytucji stojących na straży bezpieczeństwa. Oto kilka projektów socjalnych ukazujących zagrożenia bezpieczeństwa seniorów.

Projekt socjalny pod nazwą „Bezpieczny senior” został zrealizowany w Tychach przez Joannę Bebek i Pawła Grossmana. Weryfikacja raportów z policji dotyczących przestępczości i ofiar przemocy oraz raportu ruchu drogowego pozwoliła opracować katalog zagrożeń czyhających na seniorów. Diagnoza wykazała niski poziom bezpieczeństwa seniorów. Tylko w pierwszej połowie 2017 roku 30 tysięcy osób powyżej 65 lat było ofiarą przestępstw (s. 28). Jako przyczyny zagrożonego bezpieczeństwa wskazano: brak właściwego wsparcia ze strony rodziny, zbyt duże zaufanie do innych ludzi, niedostateczną wiedzę na temat praw konsumenta, niskie dochody, niedostateczną wiedzę na temat ofert wsparcia dla osób starszych, obawę przed negatywnym postrzeganiem przez innych, także osoby bliskie, opór przed kontaktami z lekarzem. Skutki są następujące: zawieranie niekorzystnych umów, utrata majątku, przemoc, zagrożenie utraty zdrowia, brak udziału w życiu społecznym i kulturowym. Celem projektu było podniesienie 
bezpieczeństwa seniorów poprzez: poszerzenie wiedzy na temat możliwości uzyskania wsparcia $\mathrm{w}$ wybranych instytucjach pomocy, wzrost identyfikacji zagrożeń, $\mathrm{z}$ jakimi mogą spotkać się seniorzy w miejscach publicznych, nabycie wiedzy na temat występujących zagrożeń związanych z bezpieczeństwem w miejscu zamieszkania. Realizacja projektu została oparta na spotkaniach z przedstawicielami różnych instytucji, takich jak: policja, straż pożarna, służba zdrowia, ZUS. Wśród nich byli: policjanci, strażak, rzecznik praw konsumenta, prawnik, pielęgniarka środowiskowa, członek zespołu do spraw orzekania o stopniu niepełnosprawności. W realizacji projektu wzięło udział około 40 seniorów. $Z$ ankiety ewaluacyjnej przeprowadzonej wśród uczestników wynika, iż projekt przyczynił się do: zwiększenia poczucia gotowości seniorów do odpowiedniego zachowania w sytuacjach zagrożenia zdrowia i życia, poszerzenia wiedzy o odpowiednim zachowaniu się w sytuacji próby kradzieży; zwiększenia pewności siebie; wzrostu wiedzy o zagrożeniach. Trafnym podsumowaniem i zachętą do realizacji tego typu projektów są następujące słowa autorki: „Pomimo istnienia kadr wyspecjalizowanych $\mathrm{w}$ pracy $\mathrm{z}$ osobami starszymi o różnym stopniu samodzielności, różnym potencjale kulturowym i kapitale społecznym, widoczny jest brak spójności podejmowanych działań, co zwiększyłoby efektywność realizacji poszczególnych celów oraz właściwsze wykorzystanie ich potencjałów" (Bebek, Grossman 2018: 64).

Przemoc to bardzo ważny temat dla seniorów, a jednocześnie problem, z którym nie zawsze skutecznie potrafią sobie poradzić. Na problem przemocy wśród seniorów zwróciła uwagę Katarzyna Myślińska-Robakowska. Dokonując diagnozy w Dąbrowie Górniczej poprzez przeprowadzenie wywiadów z seniorami, dodatkowo analizując zgłoszenia „Niebieskiej Karty” i dane statystyczne, które wskazywały na występowanie zjawiska przemocy wobec osób starszych, autorka uznała, iż należy poszerzyć wiedzę osób starszych na temat przemocy. Projekt socjalny miał na celu zwiększenie ochrony i bezpieczeństwa seniorów poprzez działania profilaktyczno-edukacyjne. Jako główny cel przyjęto podniesienie poziomu wiedzy na temat zjawiska przemocy i zagrożeń z niego płynących w środowisku życia seniorów. Celami szczegółowymi były: zwiększenie motywacji seniorów do wspólnych spotkań i rozmów na temat przemocy; wzrost wiedzy seniorów o formach i możliwościach uzyskania wsparcia; dostarczenie wiedzy na temat zjawiska przemocy i zagrożeń z nim związanych oraz poszerzenie wiedzy pracowników instytucji pracujących z seniorami na temat przemocy wobec osób starszych. Realizacja projektu objęła następujące działania: spotkania dla seniorów w gminie, nawiązanie współpracy z klubami seniorów, porady prawne i psychologiczne dla seniorów, prelekcja na temat zjawiska przemocy i zagrożeń w środowisku seniorów, spotkania edukacyjne dla pracowników instytucji pracujących z seniorami lub na rzecz seniorów. W czasie prelekcji wiele seniorek zabierało głos na temat zjawiska przemocy w rodzinie. Wśród pytań ze strony seniorów były też takie dotyczące „,klapsa - czy to już przemoc?”, , ,gwałtu małżeńskiego”, „zabierania świadczeń emerytalnych przez członków rodziny”, a także "nadużywania alkoholu przez członków rodziny" (Myślińska-Robakowska 2018: 74). W prowadzonej dyskusji seniorzy zwrócili uwagę na następujące sprawy: „nikt się nimi nie interesuje jak trzeba, bo są już starzy”; „starsi ludzie powinni być bardziej chronieni 
przez młodych i czuć się bezpieczniej, a nie czuć się zagrożeni”; „młodzi tylko piwko w głowie, a za odwiedziny chcą pieniędzy" (Myślińska-Robakowska 2018: 76). Prelekcja na temat przemocy domowej była odebrana bardzo pozytywnie i przyniosła niektórym seniorom ulgę, o czym świadczy następująca wypowiedź: „nareszcie miałam możliwość porozmawiać o tym, co się dzieje u mnie, kamień z serca chyba mi spadł, dziękuję za to spotkanie" (Myślińska-Robakowska 2018: 83). Projekt socjalny zakładał między innymi zmniejszenie skali zjawiska przemocy wobec osób starszych, nieakceptowanie przemocy w środowisku seniorów, wzrost skuteczności radzenia sobie z przemocą. Jak w zakończeniu napisała autorka projektu: „Wiedzę, którą zdobyli, będą mogli przekazywać innym seniorom, bo choćby jedno życie takiej ofiary przemocy zostanie zmienione" (Myślińska-Robakowska 2018: 87).

Przemoc ekonomiczna stanowi szczególny rodzaj przemocy wobec seniorów, gdyż obejmuje środki finansowe i dobra materialne. Sprawcy przemocy ekonomicznej wobec seniorów dopuszczają się najczęściej: pozbawienia pieniędzy na podstawowe potrzeby, ograniczenia dostępu bądź wyliczenia funduszy na opłaty i inne wydatki, kradzieży karty kredytowej, zastraszania i szantażowania ograniczeniem lub zabraniem pieniędzy z powodu braku posłuszeństwa, obrażania, wyśmiewania i podkreślania, że tylko właściwe gospodarowanie pieniędzmi przez sprawcę pozwoli osobie starszej na zaspokojenie podstawowych potrzeb, czy namawiania do podpisania kredytu dla dobra rodziny i poprawy jej funkcjonowania. W rodzinach dotkniętych przemocą: „życie rodzinne kształtowane jest wokół wartości, takich jak pieniądz i dobra materialne, które stanowią podstawę poczucia władzy i wartości sprawcy" (Dyjakon 2015: 2-3).

Projekt zwracający uwagę na przemoc ekonomiczną wobec seniorów podjęły Agnieszka Jureczko i Beata Kisiel-Alaszewicz. Diagnozy problemów seniorów dokonano na podstawie analizy danych statystycznych z: Komendy Powiatowej Policji w Wodzisławiu Śląskim, Zespołu Interdyscyplinarnego do spraw Przeciwdziałania Przemocy w Rodzinie (procedura „Niebieskiej Karty”) oraz raportu z badań przeprowadzonych w 2016 roku przez Centrum Rozwoju Inicjatyw Społecznych. Centralnym elementem tak zwanego drzewa problemów stała się bezradność seniora wobec problemu przemocy ekonomicznej. Jako przyczyny wymieniono: niewystarczającą wiedzę seniorów o możliwościach uzyskania wsparcia, niewystarczającą ofertę wsparcia instytucjonalnego, stereotypowe postrzeganie starości, zależność finansową osób starszych od członków rodziny, niskie dochody lub brak własnych dochodów, konflikty, brak więzi, złe relacje i inne problemy występujące w rodzinie osób starszych oraz niską aktywność społeczną. Skutkami są między innymi: niezaspokojone podstawowe potrzeby seniorów, pogarszający się stan zdrowia psychicznego, wykluczenie społeczne, kulturalne i instytucjonalne, pogłębiające się poczucie osamotnienia i bezradności, przemoc ekonomiczna wobec seniorów ze strony rodziny oraz pogłębiający się rozpad więzi rodzinnych. Autorki za cel główny obrały uwrażliwienie społeczności lokalnej na problem przemocy ekonomicznej wobec seniorów. W ramach projektu podjęto następujące działania: zorganizowano konferencję pod tytułem „Stop przemocy wobec osób starszych”, której prelegentami byli przedstawiciele policji, służby zdrowia, rzecznik konsumentów oraz przedstawiciel 
ośrodka wsparcia dla ofiar przemocy. Następnie zorganizowano spotkanie z księdzem proboszczem, który poruszył zagadnienia moralnej odpowiedzialności za członków rodziny, która skłania seniorów do ulegania im, stanowiąc niejako zgodę na zjawisko przemocy ekonomicznej. Kolejne spotkania odbyły się z psychologiem oraz policjantem, który przestrzegał przed przestępcami posługującymi się metodami "na wnuczka” lub „na policjanta”. Oceniając projekt, autorki podkreśliły innowacyjność tego przedsięwzięcia: „Zarówno działania nastawione na podniesienie świadomości środowiska lokalnego na problem przemocy ekonomicznej wobec osób starszych, jak i spotkania warsztatowe samych zainteresowanych dały podstawę do zakwalifikowania tych działań jako nowych i nigdy wcześniej niepodjętych" (Jureczko, Kisiel-Alaszewicz 2018: 80). Owa innowacyjność przekłada się na przyszłe działania. Planuje się stworzenie sieci wsparcia na rzecz seniorów zagrożonych przemocą ekonomiczną oraz istnieje propozycja współpracy międzyinstytucjonalnej w celu ulepszenia systemu pomocy seniorom (Jureczko, Kisiel-Alaszewicz 2018).

Zagrożone bezpieczeństwo seniorów nie jest mitem, ale faktem, o czym przekonują nas dane zawarte w projektach ukazujące seniorów jako ofiary przemocy. Projekty socjalne tworzone $\mathrm{z}$ myślą o bezpieczeństwie seniorów wskazują nam pewne deficyty ochrony w tym zakresie. Wynikają one z dwóch źródeł. Pierwsze jest związane z niskim poziomem wiedzy osób starszych o możliwościach korzystania z różnych form pomocy, w tym instytucjonalnej. Drugie zaś ukazuje słabość instytucji stojących na straży bezpieczeństwa oraz brak współpracy między nimi w zakresie zorganizowanych działań mających na celu podniesienie świadomości o możliwych formach pomocy. Ludzie powinni wiedzieć, gdzie i jakie instytucje stoją na straży bezpieczeństwa oraz mieć świadomość, które zachowania stanowią znamiona przemocy. W tym miejscu należałoby postawić pytanie, czy tylko pracownicy socjalni powinni czuwać nad bezpieczeństwem seniorów? Czy przedstawiciele innych instytucji robią wszystko w tym zakresie? W jaki sposób i jakie służby powinny wzmocnić czujność, aby seniorzy poczuli się bezpieczniej? W przypadku osób starszych szczególnie dotkliwa, i jednocześnie trudna do odkrycia, jest przemoc ekonomiczna rodzinna. Zbyt wielu seniorów, wychowywanych w zupełnie innych warunkach społecznych, politycznych, kulturowych i gospodarczych, ceni rodzinę jak „świętość”, i nawet gdy dzieje się im krzywda, nie są w stanie ujawniać czegokolwiek, a tym bardziej oskarżać najbliższych. Tak rozpowszechnione wyłudzenia "na wnuczka” są dowodem, iż seniorzy dla dzieci czy wnucząt - a w domyśle dla dobra rodziny - są gotowi „na wszystko”.

\section{„Seniorze nie jesteś sam”}

W sytuacjach gdy ludzie doświadczają różnych problemów, trudności, a nawet porażek, nic tak nie potrafi podnieść ich na duchu jak świadomość, że są wśród nas inni, którzy także przechodzili podobną drogę. Dotyczy to ludzi w każdym wieku, nie tylko seniorów. Na takiej zasadzie działają grupy samopomocy, które zawiązują się, łącząc 
ludzi z podobnymi problemami. Świadomość, że nie jesteśmy sami, działa bardzo kojąco nawet w traumatycznych sytuacjach. Chodzi tu o wsparcie, jakie mogą dać nam inni. Jednak ruch należy także do nas, czyli my sami musimy być otwarci na wsparcie i gotowi je przyjąć.

Czytając tytuł projektu „Seniorze nie jesteś sam”, dwóch autorek Beaty Supruniuk i Joanny Zawadzkiej, przychodzi mi na myśl pomysł, aby w każdej miejscowości, małej i dużej, mieście i wiosce, założyć stowarzyszenie pod takim właśnie tytułem. Już sam napis podnosi na duchu. Projekt został zrealizowany z myślą o samotnych seniorach. Osamotnienie seniorów to główny problem - i szczególnie dotkliwy. Diagnoza problemów przeprowadzona przez autorki projektu za pomocą ankiety wykazała, iż przyczyny osamotnienia seniorów są złożone. Należą do nich między innymi: brak rodziny, zerwane więzi, eurosieroty $70+$, konflikty w rodzinie, bariera międzypokoleniowa, nieakceptowanie własnej starości, przejście na emeryturę, niski status materialny, brak czasu rodziny (dzieci, krewnych) dla seniora, choroba bliskiego członka rodziny, śmierć współmałżonka lub partnera, pęd życia, za którym seniorzy nie nadążają, brak możliwości spędzania wolnego czasu przez osoby starsze, zachowania przemocowe, na przykład zaniedbanie, które ma wpływ na osamotnienie człowieka starszego. Skutki osamotnienia osób starszych są bardzo groźne dla nich samych: brak poczucia sensu życia i bycia potrzebnym, uzależnienie od leków i suplementów diety, hipochondria, stany depresyjne, łatwowierność, pogorszenie warunków życiowych, izolacja od znajomych i rodziny, podejmowanie prób samobójczych, śmierć. Celem projektu było zwiększenie aktywności społecznej seniorów. Jako cele szczegółowe założono: poprawę kontaktu osób starszych z otoczeniem, rozwój zainteresowań i umiejętności uczestników projektu, promowanie aktywności społecznej i kulturalnej osób starszych, promocję zachowań prozdrowotnych, budowanie systemu współpracy i wsparcia dla przedsięwzięć na rzecz seniorów, poszerzenie wiedzy o starości z uwzględnieniem specyfiki adaptacji, podniesienie samooceny, poprawę samopoczucia, nabycie umiejętności współdziałania w grupie, zdobycie wiedzy na temat nadmiernego stosowania leków i suplementów diety. Tak postawione cele projektu poddano realizacji poprzez liczne spotkania z następującymi osobami: przedstawicielem Radu Senioralnej, który omówił między innymi zasady uzyskania karty seniora; prezesem UTW, który przedstawił ofertę wykładów i zasady przystąpienia do UTW; dyrektorem ośrodka pomocy, który zaprezentował oferty pomocy dla seniorów; kierownikiem ŚDS, który nakreślił warunki uczestnictwa w zajęciach. Ponadto zorganizowano warsztaty pierwszej pomocy $\mathrm{z}$ ratownikiem medycznym i pielęgniarką. Do ciekawych ofert należały warsztaty poprawy własnego wizerunku $\mathrm{z}$ konsultantką AVON oraz warsztaty poprawy samopoczucia z fizjoterapeutą. Ponadto zorganizowano warsztaty rękodzieła i spotkanie w bibliotece. Zwieńczeniem projektu był udział w pikniku „Gość w dom” oraz impreza integracyjna. Projekt cieszył się dużym zainteresowaniem, został oceniony przez uczestników bardzo pozytywnie. Ponadto - jak zauważyły autorki - nastąpiła widoczna przemiana w uczestnikach projektu, którzy zaczęli otwarcie mówić o problemach związanych z osamotnieniem. Projekt socjalny zwrócił także uwagę lokalnych 
instytucji „na problem osamotnienia wśród osób starszych” (Supruniuk, Zawadzka 2017: 75). Autorki podjęły decyzję o kontynuowaniu tego typu działań.

W odpowiedzi na osamotnienie osób starszych powstał kolejny projekt socjalny, Marzanny Bieniady i Beaty Krat, pod tytułem „Ożywić starośc”, realizowany w Ełku. W celu dokonania diagnozy problemu samotności autorki przeprowadziły badania wśród seniorów. Realizację projektu poprzedziła analiza SWOT. Z uwagi na zbyt dużą liczebność przytoczę tylko niektóre $\mathrm{z}$ mocnych i słabych stron oraz wybrane szanse i zagrożenia. Mocnymi stronami były między innymi: tworzenie instytucjonalnych form pomocy seniorom, wysokie kompetencje pracowników instytucji pomocy społecznej, rozwinięta sieć edukacyjna skierowana do osób starszych, jak na przykład UTW, chęć dzielenia się wiedzą i doświadczeniem oraz dyspozycyjność osób starszych. Za słabe strony uznano: niewystarczającą diagnozę problemów i potrzeb osób starszych, ograniczony dostęp do usług środowiskowych i instytucjonalnych, zwłaszcza na terenach wiejskich, słaby poziom zainteresowania władz samorządowych problemem starzenia się, niewystarczające zainteresowanie społeczeństwa problemami osób starszych, brak wykorzystania potencjału osób starszych, zmniejszenie się roli rodziny w zakresie opieki nad seniorami, zanik tradycji rodzin wielopokoleniowych, nieprzygotowanie do starości osób przechodzących na emeryturę, stereotypy na temat starości - postrzeganie seniorów jako osób schorowanych i o niskich dochodach. Wśród zagrożeń znalazły się: brak promocji aktywności osób starszych, niewielka chęć uczestnictwa w zajęciach, zmniejszenie poczucia odpowiedzialności rodziny za osoby starsze umieszczane w DPS, przedmiotowe traktowanie osób starszych przez personel DPS, niskie kryterium dochodowe uprawniające do korzystania z pomocy społecznej, kult osoby młodej i sprawnej funkcjonujący w społeczeństwie i mediach. Jako szanse dostrzeżono: kierunki zmian w polityce dotyczące osób starszych, dostrzeganie problematyki seniorów przez samorząd lokalny, możliwość pozyskania środków finansowych z funduszy pomocowych na rzecz osób starszych, zwiększenie zainteresowania mediów problemami seniorów, promowanie różnych form aktywności i osiągnięć osób starszych, możliwość wykorzystania potencjału osób starszych. Ożywienie starości założono osiągnąć poprzez takie cele szczegółowe, jak: aktywne spędzanie czasu wolnego, wzmocnienie poczucia własnej wartości i wiary we własne możliwości, podniesienie samooceny, pozytywną konstruktywną postawę wobec starości, zrozumienie i akceptację starości jako naturalnej fazy życia, zwiększenie motywacji do uczestnictwa w życiu zbiorowym, promowanie pozytywnych wzorców spędzania czasu wolnego, wzrost poczucia panowania nad własnym życiem, pogłębienie więzi międzyludzkich, stymulowanie sprawności intelektualnej osób starszych, propagowanie otwartości na nowe doświadczenia, rozwój kreatywności seniorów. W realizację projektu zaangażowano gównie psychologów i dietetyków. Spotkania z psychologiem przebiegały pod takimi hasłami, jak: "Co to jest starość”, „Asertywność”, „Alkoholizm”, „Szkodliwość zdrowotna nikotyny”. Natomiast spotkaniom z dietetykiem towarzyszyły hasła: „Diety w jadłospisie”, „Sól i cukier”, „Ruch”, „Zdrowa starość”. Ponadto uczestnicy projektu wzięli udział w „zabawie wielkanocnej przy muzyce, jaką lubimy” oraz "majówce”. Oglądnęli film Piękna 
i bestia. Uczestniczyli w zajęciach „Woda - źródło życia”. Korzyści z tak zrealizowanego projektu dostrzeżono w trzech aspektach: socjologicznym - pobudzenie inicjatywy i aktywności społecznej uczestników, psychologicznym - zmiana sposobu zachowania na poziomie osobowościowym, to jest uaktywnienie, wzmocnienie, dowartościowanie, oraz wychowawczym - ukazanie uczestnikom i środowisku aktywności własnej w przezwyciężeniu osamotnienia.

Diagnozy potrzeb i problemów osób starszych prezentowane w projektach nie pozostawiają wątpliwości, iż jest to szczególna grupa społeczna wymagająca wsparcia. Samotność staje się zmorą seniorów, podobnie jak choroby. Realizowane projekty uświadamiają nam, iż nie można seniorów pozostawić samym sobie, ale należy otoczyć ich wsparciem. Należy mobilizować wszelkie siły służb społecznych, gdzie tylko to możliwe, do pomocy osobom starszym. Niestety, tych seniorów trzeba odszukać, zachęcić, zmobilizować i zainspirować. Nie można liczyć na to, że oni sami się do nas zgłoszą. A to oznacza pracę na wielu płaszczyznach i w wielu sferach życia społecznego.

Projekty ukazują ogromny wpływ psychologów na seniorów w zakresie podniesienia pewności siebie, własnej wartości, wiary we własne siły i możliwości. Być może przed nimi stoi największe wyzwanie „starzejącego się społeczeństwa”. Bez należytego wsparcia istnieje obawa, iż seniorzy, pozostawieni sami sobie, „zaszyją się” we własnych domach czy mieszkaniach i pogrożą w smutnej samotności.

\section{Wnioski}

Inicjatywy podejmowane przez pracowników socjalnych dla osób starszych z jednej strony ukazują problemy i potrzeby seniorów, a z drugiej niosą wielką nadzieję na zmianę. Problemy, z jakimi zmagają się osoby starsze, powinny niepokoić wszystkich nas, a nie tylko ludzi zatrudnionych w zawodach pomocowych. Nikt nie powinien czuć się zwolniony z odpowiedzialności za pomoc seniorom. Projekty socjalne uświadamiają nam złożoność problemów seniorów, ich przyczyny i skutki, a jednocześnie przekonują nas, iż zmiana jest możliwa. Aby jej dokonać, potrzebna jest mobilizacja społeczeństwa. Aby tak się stało, konieczna jest świadomość potrzeb i problemów seniorów. Bez tego nie jesteśmy w stanie ani dostrzec, ani badać, ani działać, ani wspierać, ani też pomagać osobom starszym.

Zaprezentowane wyżej projekty pokazały, iż inicjatorem zmian może być pracownik socjalny, a polem działania - lokalna społeczność i środowisko zamieszkania. W żadnym z projektów pracownik socjalny nie był sam. Wszystkie z nich zostały zrealizowane w sposób holistyczny, obejmujący i wciągający do zadań różnych specjalistów, profesjonalistów i lokalne służby - słowem ludzi fachowo pomagających. Spotkania z seniorami nie miały charakteru tylko „szkoleniowego”, ale towarzyszyły im różne atrakcje, takie jak: ogniska, zabawy, imprezy, nieformalne spotkania, biesiady, tańce czy nawet integracyjne spędzanie czasu wolnego przy ciastku i kawie. Ponadto projekty okazały się niskobudżetowe; wiele z nich nie przekroczyło 1000 złotych, a na każdy udało się 
pozyskać lokalnego sponsora. Jak przyznawali sami pracownicy socjalni, wszystkie projekty skierowane do osób starszych były innowacyjne, także w tym znaczeniu, iż nikt nigdy wcześniej w danej miejscowości czegoś podobnego nie zorganizował. Wreszcie warto podkreślić, iż w większości nie były to jednorazowe działania. Realizacja projektu stawała się początkiem czegoś niepowtarzalnego, kontynuowania pomysłu w przyszłości, realizacji podobnych działań dla seniorów. Ale też pobudzała do refleksji nad obecnym stanem, ułatwiała rewizję aktualnych ofert dla seniorów, ujawniała niedoskonałości, deficyty i brak koordynacji działań w danej lokalnej społeczności. Projekty stały się zatem okazją także do rewizji działań, wyciągania wniosków i mobilizacji instytucji do bardziej efektywnego działania na rzecz seniorów.

Projekty stają się pomocne także jeśli chodzi o zmianę wizerunku pracownika socjalnego i związanych z nim stereotypów, na przykład „urzędnika rozdającego pieniądze”. Ukazały pracowników socjalnych w zupełnie innym świetle - jako osoby pomysłowe, animatorów różnych działań, gotowe na nowe wyzwania, dostrzegające problemy lokalnej społeczności, odważne w realizacji postawionych celów i zdeterminowane do zmiany utartych schematów. Jest to nowa jakość pracy socjalnej i nowa rola pracownika socjalnego. Sami pracownicy socjalni w projektach udowodnili, iż można zrobić „coś więcej” dla ludzi niskim nakładem finansowym, wykorzystując lokalne zasoby, środki i możliwości. Miejmy nadzieje, że znajdą się naśladowcy podobnych inicjatyw nie tylko $\mathrm{w}$ ramach podnoszonych kwalifikacji i specjalizacji w zawodzie pracownika socjalnego, lecz także wśród innych zawodów i profesji, dla dobra człowieka i społeczeństwa.

\section{Bibliografia}

Dyjakon D. (2015). Przemoc ekonomiczna - ukryta nić zniewolenia. „Niebieska Linia”, 6: 2-3.

Kamiński A. (1976). Podstawowe pojęcia pedagogiki społecznej. Instytut Wydawniczy CRZZ, Warszawa.

Kijak R.J., Szarota Z. (2013). Starość. Między diagnozq a działaniem. Centrum Rozwoju Zasobów Ludzkich, Warszawa.

Klimczuk A. (2013). Kreatywne starzenie się. Przykłady zagranicznych zaleceń i praktyk, w: A. Zawada, Ł. Tomczyk (red.), Seniorzy w środowisku lokalnym (badania empiryczne i przykłady dobrych praktyk). UŚ, Katowice: 24-46.

Krzyszkowski J. (2018). Deinstytucjonalizacja usług dla seniorów jako element polityki senioralnej. „Problemy Polityki Społecznej. Studia i Dyskusje”, 3: 37-52.

Mielczarek A. (2010). Człowiek stary w domu pomocy społecznej. Z perspektywy polityki społecznej i pracy socjalnej. Wydawnictwo AKAPIT, Toruń.

Ornacka K. (2012). Ewaluacja w pracy socjalnej - wyzwanie dla współczesnego profesjonalisty, w: M. Banach, J. Matejek (red.), Z teorii i praktyki pracy socjalnej. Wydawnictwo MTM-Lewocza: 41-57.

Skidmore R.A., Thackeray M.G. (1996). Wprowadzenie do pracy socjalnej. Interart, Warszawa. 
Szarota Z. (2010). Starzenie się i starość w wymiarze instytucjonalnego wsparcia. Uniwersytet Pedagogiczny, Kraków.

Szatur-Jaworska B. (1995). Teoretyczne podstawy pracy socjalnej, w: T. Pilch, I. Lepalczyk (red.), Pedagogika społeczna. Człowiek $w$ zmieniającym się społeczeństwie. Wydawnictwo „Żak”, Warszawa: 112-129.

Szatur-Jaworska B. (red.) (2018). Polityki publiczne. Wybrane zagadnienia teoretyczne i metodologiczne. Wydawnictwa Uniwersytetu Warszawskiego, Warszawa.

Szatur-Jaworska B., Błędowski P. (red.) (2017). System wsparcia osób starszych $w$ środowisku zamieszkania. Propozycja modelu oraz wyniki badania antydyskryminacyjnego. Synteza. Rzecznik Praw Obywatelskich, Warszawa.

Ustawa o pomocy społecznej z dnia 12 marca 2004 roku (Dz.U. z 2004 r. Nr 64 poz. 593).

\section{Materiały źródłowe (projekty socjalne)}

Alejster I. (2017). Mogę więcej - aktywność seniorów w ramach Uniwersytetu Trzeciego Wieku. Olsztyn.

Bebek J., Grossman P. (2018). Bezpieczny senior. Opole.

Bieniada M., Krat B. (2017). Ożywić starość. Olsztyn.

Jureczko A., Kisiel-Alaszewicz B. (2018). „Niewidzialni” - profilaktyka przemocy ekonomicznej wobec osób starszych. Katowice.

Myślińska-Robakowska K. (2018). „Bezpieczny Senior”. Działania profilaktyczno-edukacyjne zwiększające wiedzę na temat zjawiska przemocy w środowisku seniorów w gminie Dąbrowa Górnicza. Katowice.

Proć I., Tomes B. (2018). Aktywizacja i integracja mieszkańców Domu Pomocy Społecznej we Wrocławiu przy ul. Rędzińskiej poprzez organizację warsztatów teatralnych - projekt socjalny „Świat jest teatrem, aktorami ludzie...” Opole.

Ruszczyk A. (2017). Teraz Senior - integracja społeczna i kulturalna seniorów Gminy Gietrzwałd. Olsztyn.

Supruniuk B., Zawadzka J. (2017). „Seniorze nie jesteś sam”. Olsztyn. 